\title{
PENCIPTAAN KARYA SENI RUPA ABSTRAKSI WAJAH TOGOG DAN TOPENG BUJANG GANONG DENGAN TEKNIK CBT (CETAK BENANG TARIK)
}

\author{
Much. Sofwan Zarkasi' Bening Tri Suwasono \\ ${ }^{1}$ Jurusan Seni Rupa Murni, ${ }^{2}$ Jurusan Kriya Seni \\ Fakultas Seni Rupa dan Desain, Institut Seni Indonesia(ISI) Surakarta \\ Email: sofwanzarkasi@gmail.com \\ Email: bening_trisuwasono@yahoo.co.id
}

\begin{abstract}
"Penciptaan Karya Seni Rupa Abstraksi Wajah Togog Dan Topeng Bujang Ganong Dengan Teknik CBT (Cetak Benang Tarik)"'( The Creation Of Abstraction Artworks Of Togog's Face And The Mask Of Bujang Ganong With CBT (Print Thread) Technique) by Sofwan Zarkasi and Bening Tri Suwasono is based on the opportunities related to creativity and experimentation in two-dimensional works of art that utilize systems or techniques of creation in graphic arts, which have two-dimensional print art characters. One of them is creating mono print graphic artwork with a print process that utilizes tensile threads, namely threads that are colored and printed on paper and pulled with a little pressure. This research aims to open wide opportunities for creativity in two-dimensional works of art.

The method applied in the creation of works in this study is using the theoretical approach of L. Chapman, which mentions three stages. The first stage is finding ideas by approaching the source of inspiration; the second stage includes refinement, development and establishment of the initial idea, including how the artist perfects, develops and establishes the initial idea which in this case relates to the search of forms, the choice of medium, tools, materials, and techniques; and the third stage, visualization into media, namely how artists visualize in the media. Indirectly the theory also put forward the experimentation, which in this study is the technique of Tensile Print (CBT) which produces the image prints in the form of lines that form the visual subject of Togog's face and Bujang Ganong's face mask in two-dimensional media. The results of this aristic research are two-dimensional works of art in the form of abstractions of Bujang Ganong masks with the characteristics of printed characters from the attraction of colored threads. From the creation of abstraction artworks of Togog's face and the mask of Bujang Ganong with CBT (Print Thread) technique, this two-dimensional art works with the traditional dimensions is expected to be rich of innovation, both in technique and form, so that it can raise the prestige of the arts.
\end{abstract}

Keywords: Fine Arts, two dimensions, abstraction, puppets, CBT.

\section{PENDAHULUAN}

\section{A. Latar Belakang}

Perkembangan seni rupa di era baru ini, dalam aparesiasinya, tidak lagi mengkotakkotakkan bidang ilmu, namun saling terbuka dengan berbagi kreatifitas teknik maupun karakter seni di antara seni yang lain. Seni rupa sendiri membicarakan wilayah keilmuan praktikal yang sarat dengan proses ketrampilan membuat visualisasi estetis yang dipengaruhi oleh perasaan, psikologis, maupun keadaan lingkungan seniman. Perkembangan seni rupa yang berkembang sekarang telah membuka peluang terbukanya ide-ide kreatif terkait bentuk, teknik dan media yang digunakan dalam berkarya seni.

Seni cetak mencetak sebagai salah satu bagian dari seni fine art yang mengedepankan kebutuhan berkreasi seni, yang muncul dari dalam diri seniman, juga telah mengalami banyak perkembangan, baik dari segi bentuk teknik dan media. Salah satu teknik dasar dalam 
seni cetak adalah seni Cetak Benang Tarik (CBT), yang memanfaatkan sistem monoprint atau sekali cetak.

Teknik cetak CBT ini secara kontinyu juga menjadi bahan yang peneliti ajarkan dalam matakuliah nirmana, dengan hasil visual bentuk-bentuk abstrak. Melalui teknik CBT, peneliti melihat peluang menarik untuk mengembangkan visual yang bisa dihasilkan dengan teknik CBT ini, salah satunya adalah visual figur tokoh pewayangan.

Melalui teknik CBT ini dilakukan eksperimentasi terkait teknik, media, maupun bentuk karya seni rupa yang ingin diciptakannya. Teknik CBT digunakan untuk menghasilkan karya seni rupa dua dimensi, cetakan benang tarik yang membentuk visual artistik dari bekas cetakan dan tarikan benang yang telah dilumuri atau diberi warna.

Penelitian penciptaan karya ini mengambil judul Penciptaan Karya Seni Rupa Abstraksi Wajah Togog dan Topeng Bujang Ganong Dengan Teknik CBT (Cetak Benang Tarik). Karya inovasi seni rupa dua dimensi yang memanfaatkan teknik CBT dan mono print ini diharapkan dapat memperkaya teknik dan bentuk dalam seni rupa.

\section{B. Tujuan Khusus}

Tujuan khusus penelitian "Penciptaan Karya Seni Rupa Dua Dimensi Dengan Teknik CBT (Cetak Benang Tarik)" ini adalah menciptakan karya seni rupa dua dimensi yang memanfaatkan teknik garap dalam seni cetak atau seni grafis yaitu teknik CBT. Selain itu penelitian artistik ini juga menghasilkan laporan yang bertujuan :

1. Menjelaskan Konsep Penciptaan Karya Seni Rupa Abstraksi Wajah togog dan Topeng Bujang Ganong Dengan Teknik CBT (Cetak Benang Tarik)

2. Menjelaskan proses Penciptaan Karya Seni Rupa Abstraksi Wajah Togog dan Topeng Bujang Ganong Dengan Teknik CBT (Cetak Benang Tarik)
3. Menjelaskan bentuk Karya Seni Rupa Abstraksi Wajah Togog dan Topeng Bujang Ganong Dengan Teknik CBT (Cetak Benang Tarik)

Penelitian ini diharapkan mampu menginspirasi seniman atau perupa untuk selalu berkarya, bereksperimentasi dan menghasilkan karya-karya seni yang kreatif, sehingga seni rupa semakin kaya dan berkembang.

\section{Urgensi Penciptaan}

Seniman adalah manusia kreatif. Aktivitas kreatif memanfaatkan material dalam setiap bidang seni. Menyumbangkan pengharuman jiwa dan martabat kita sebagai bangsa dan seorang seniman yang unggul. Terkait dengan keterangan di atas, tugas seorang seniman yang juga sebagai agen kultural jelas tidak hanya bisa menciptakan karya seni secara kuantitas, tapi secara kualitas juga harus ditunjukkan dengan selalu menghadirkan pemikiranpemikiran kreatif dalam bereksperimentasi seni, mencoba menghadirkan, mengeksplorasi dan menyatukan nilai-nilai kebermainan dan pemberontakan menjadi proses kreatif yang mengarah terciptanya karya seni rupa yang baru dan inovatif.

Di tengah-tengah arus globalisasi yang sukar sekali dihadang, muncullah kecenderungan untuk menemukan kembali Indonesian Heritage sebagai pola pengakuan jati diri dan refleksi identitas pribadi bangsa Indonesia. Salah satunya adalah peluang mengawinkan beberapa hal yang berkaitan dengan seni tradisi yang sudah ada, contohya adalah figur pewayangan dikawinkan dengan karya seni yang inovatif berupa karya seni rupa dua dimensi dengan teknik CBT.

Penelitian artistik ini memunculkan abstraksi wajah Togog dan topeng Bujang ganong sebagai salah satu karakter visual tradisi Indonesia. Perkembangan karya seni grafis yang kalah populer dengan karya seni lukis, salah 
satunya karena pemahaman para penggrafis yang kadang masih kaku hanya pada teknis dan media yang selama ini digunakan dalam penciptaan karya seni grafis, yaitu relief print (cetak tinggi), intaglio (cetak dalam), planography (cetak datar), serigraphy (cetak saring). Para seniman grafis dalam hal ini dituntut untuk bisa memiliki sudut pandang yang luas terkait teknik dan media yang membuka peluang kekaryaan seni grafis yang lebih berkembang dengan tetap berpijak pada konsep cetak mencetak.

Keterbukaan pemikiran dan pemahaman yang dalam akan penciptaan karya seni rupa perlu diaktualisasikan dalam bentuk penciptaan karya yang inovatif secara kontinyu, sehingga kecintaan terhadap karya-karya seni rupa menjadi lebih terasa. Bagi khalayak pun karya seni rupa inovatif yang semakin variatif akan menjadi menu baru dalam menikmati karya seni rupa. Salah satunya eksperimentasi Penciptaan Karya Seni Rupa Dua Dimensi Dengan Teknik CBT (Cetak Benang Tarik) dengan visual topeng wajah Bujang Ganong.

\section{KAJIAN LITERATUR DAN PENGEMBANGAN HIPOTESIS}

Penelitian artistik ini menerapkan teknik eksperimentasi dari sistem kerja dalam teknik cetak benang tarik. Hasil penelitian atau tulisan tentang seni cetak benang tarik ini memang belum banyak dibuat, kebanyakan teknik ini diajarkan sebagai teknik kreatif dalam teknik dasar seni rupa. Beberapa dalam materi ajar untuk anak-anak, seperti pada tulisan materi ajar dari Ni komang Andini yang menuliskan, tentang teknik tarik benang dalam seni rupa.

Teknik tarik benang ini merupakan cara membuat kreasi hasil gambar bebas yang dilakukan dengan mencelupkan benang ke dalam adonan pewarna dan meletakkan benang yang sudah dicelupkan ke dalam adonan pewarna jika ingin menghasilkan warna yang bermacammacam, lakukan ke dalam empat warna yang ada. Atau kalau ingin membuat warna baru bisa bereksperimen membuat warna baru dan meletakkan benang ke dalam pewarna. Alat dan bahan yang biasa digunakan dalam teknik tarik benang ini yaitu kertas gambar, pewarna makanan (merah, kuning, biru dan hijau), lap, kertas koran dan benang kasur. ${ }^{1}$

Karya-karya yang dihasilkan dengan teknik benang tarik ini pun kebanyakan dalam bentuk abstrak. Belum ada karya dengan teknik benang tarik ini yang berupa membentuk visual subyek tertentu. Penelitian ini diharapkan akan menghasilkan karya seni rupa dua dimensi dengan teknik benang tarik yang visualnya berupa abstraksi figur tokoh pewayangan.

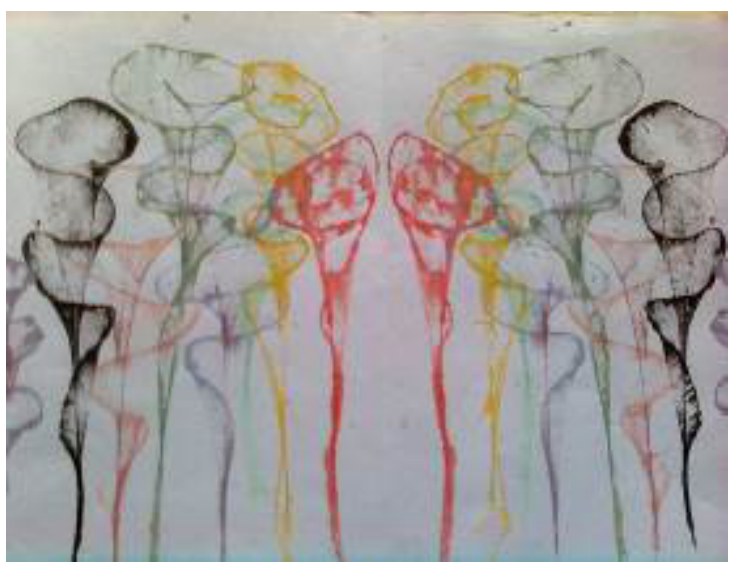

Gambar 1. Karya seni rupa

cetak benang tarik, pada http://ulfakarunia.

blogspot.com/2012/07/gambar-tarikan-benang. html

download oleh Zarkasi 2018

Bentuk topeng Bujang Ganong dipilih sebagai proses keberlanjutan penggunaan karakter visual dalam seni tradisi khususnya wayang dalam beberapa penelitian yang sudah dilakukan. Pada tahun 2007, peneliti melakukan penelitian kekaryaan seni dengan judul penelitian "Figur Wayang Purwa dan Wayang Wong Sebagai Sumber Ide Penciptaan

$1 \quad$ Ni komang Andini, The Proses of Life, Materi Teknik Inkblot, Tarik Benang atau Tarikan dan finger painting pelajaran ke 3 dalam http://nikomangandini. blogspot.com/2017/06/materi-teknik-inkblot-tarikbenang-atau.html undu oleh Zarkasi 2018 
Karya Seni Grafis dengan Teknik Komputer" yang menghasilkan karya digital printing dengan menampilkan visual tokoh atau figur-figur dalam wayang Purwa. Pada tahun tersebut karya seni grafis dengan teknik cetak digital masih jarang, padahal proses yang berbau digital sedang naik daun dan disukai anak muda. Penelitian tersebut juga memiliki tujuan yang salah satunya sebagai stimulus, bagi remaja untuk tertarik mengenal pewayangan.

Penelitian kekaryaan seni grafis yang peneliti lakukan selanjutnya adalah, pada tahun 2008, "Studi Penciptaan Karya Seni Grafis Dengan Teknik Hot Print Di Atas Kaca". Penelitian tersebut menhasilkan karya seni grafis di atas kaca dengan teknik hot print, yaitu proses mentrasfer gambar dengan sistem atau alat pemanas, menggunakan tinta sublim. Selain teknik hot print, penelitian ini juga menampilkan karya seni grafis di atas kaca yang memiliki kesan tiga dimensi karena terdiri dari kaca yang berlapis lebih dari satu sesuai dengan efek dimensi yang ingin dimunculkan.

Eksistensi kreatif dalam rangka memunculkan Indonesian Heritage ini diharapkan bisa, salah satunya, menjadi peluang mengawinkan beberapa hal yang berkaitan dengan seni tradisi yang sudah ada, contohya adalah figur pewayangan dikawinkan dengan karya seni yang inovatif berupa karya seni rupa dua dimensi dengan teknik CBT.

\section{METODE PENELITIAN}

\section{A. Pendekatan}

Seperti yang sudah dijelaskan pada latar belakang penciptaan Karya Seni Rupa Abstraksi Wajah Togog dan Topeng Bujang Ganong Dengan Teknik CBT (Cetak Benang Tarik), penciptaan karya ini menggunakan pendekatan teori L.H Chapman, yaitu: pertama, tahap menemukan gagasan, yaitu mendekati sumber inspirasi; ke dua tahap penyempurnaan, pengembangan dan pematapan gagasan awal, yaitu bagaimana seniman menyempurnakan, mengembangkan dan memantapkan gagasan; dan tahap ke tiga visualisasi ke dalam media. Dalam penelitian ini secara khusus juga dilakukan beberapa tahapan riset, yaitu riset etik, emik dan kreasi artistik.

\section{B. Langkah-Langkah Penelitian}

\section{Menemukan Gagasan}

\section{a. Riset Etik}

Penelitian ini dalam menemukan gagasan-gagasan penciptaan karya dengan mendekati sumber ispirasi melakukan beberapa kajian dan studi pustaka dari beberapa tulisan atau buku tentang seni rupa, seni grafis, figur wayang dan beberapa informasi tertulis yang berhubungan dengan proses eksperimentasi yang sudah pernah dilakukan sebagai sumber dan kekayaan materi pendukung proses penelitian artistik yang dilakukan.

Secara umum buku yang membahas tentang teknik benang tarik ini masih sebatas materi ajar di lingkungan guru-guru SD yang tergabung pada Persatuan Guru Sekolah Dasar (PGSD), seperti pada materi ajar Pendidikan Seni Rupa dan Kerajinan STKIP PGRI TULUNGAGUNG PGSD, yang materi ajarnya memuat teknik benang tarik. ${ }^{2}$

Metode teknik benang tarik biasanya menjadi bahan dan materi ajar anak-anak karena merupakan materi dengan bahan sederhana yang memiliki pengaruh pendidikan kreatif secara dasar untuk anak, seperti untuk melatih koordinasi mata, tangan dan kelenturan tangan bagi anak. $^{3}$

Selain itu peneliti juga mengadakan kajian tentang figur tokoh pewayangan yang

2 http://anikrahayunigsih.blogspot. com/2015/11/hasil-karya-tarikan-benang-ink.html

3 Eca Trisnahayu, 2014 , Meningkatkan Melalui Permainan Warna Dengan Media Benang Pada Anak Kelompok B Paud Nurul Amal Desa Betungan Kecamatan Kedurang Ilir Kabupaten Bengkulu Selatan, Sekripsi Program Sarjana (S1) Kependidikan Bagi Guru Dalam Jabatan Pendidikan Anak Usia Dini (Paud) Fakultas Keguruan Dan Ilmu Pendidikan Universitas Bengkulu, hal. 27 
menjadi bagian keunikan dari karya penelitian artistik ini. Antara lain dari buku tulisan Agus Ahmadi berjudul Kriya Wayang Kulit Purwa Gaya Surakarta, cetakan 1, 2014, dan buku tulisan Sulardi berjudul Gambar Prinjening Ringgit Purwa. Melalui buku-buku tersebut ditemukan beberap figur tokoh pewayangan yang menarik untuk dipilih menjadi obyek visual. Beberapa figur pewayangan yang dibuat sebagai subyek visual dalam penciptaan karya seni dua dimensi dengan teknik CBT ini adalah: tokoh raksasa, tokoh Punokawan, Cangik, Limbuk dan beberapa tokoh pewayangan lainnya. Selain itu juga beberapa tokoh dalam cerita wayang Panji Asmorobangun, yang salah satunya adalah tokoh Bujang Ganong.

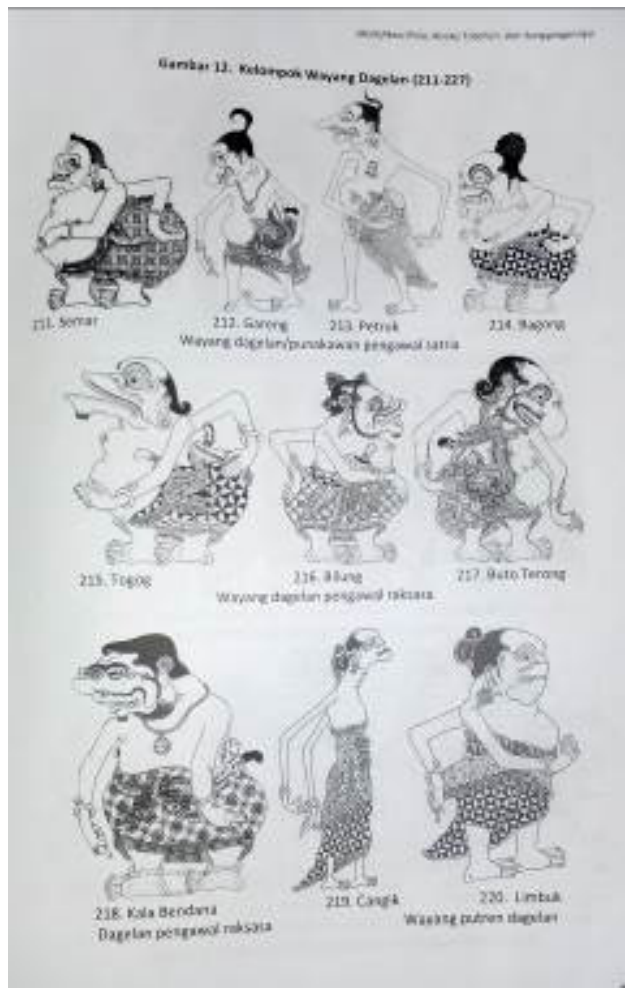

Gambar 2. Refrensi beberapa figur tokoh pewayangan dalam buku berjudul "kriya Wayang Kulit Purwa", penulis Agus Ahmadi, foto oleh Zarkasi 2018

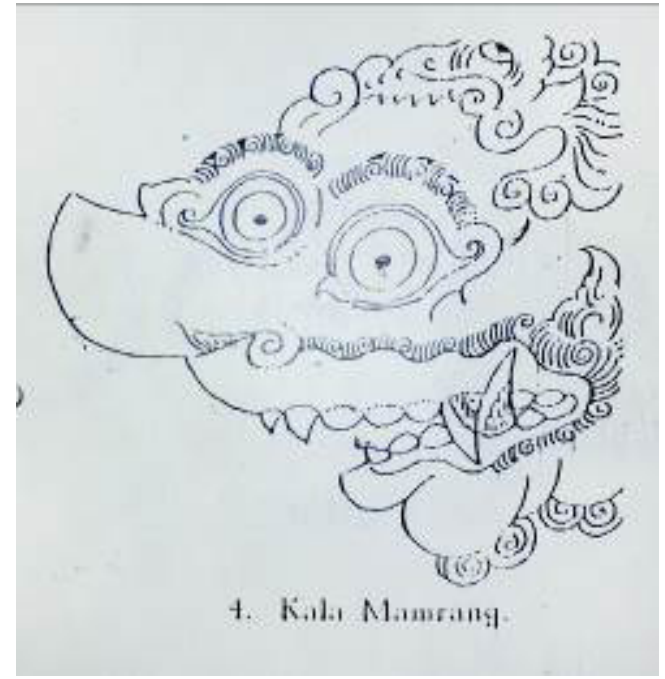

Gambar 3. Refrensi wajah tokoh raksasa dalam buku berjudul "Gambar Prinjening Ringgit Purwa", penulis Sulardi, foto oleh Zarkasi 2018

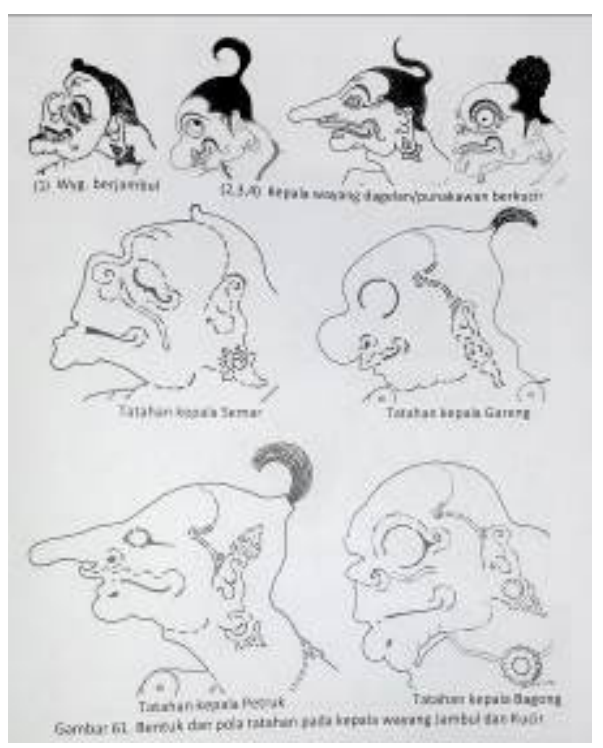

Gambar 4. Refrensi beberapa figur tokoh Punokawan dalam buku berjudul "kriya Wayang Kulit Purwa", penulis Agus Ahmadi, foto oleh Zarkasi 2018 


\section{Asintya}
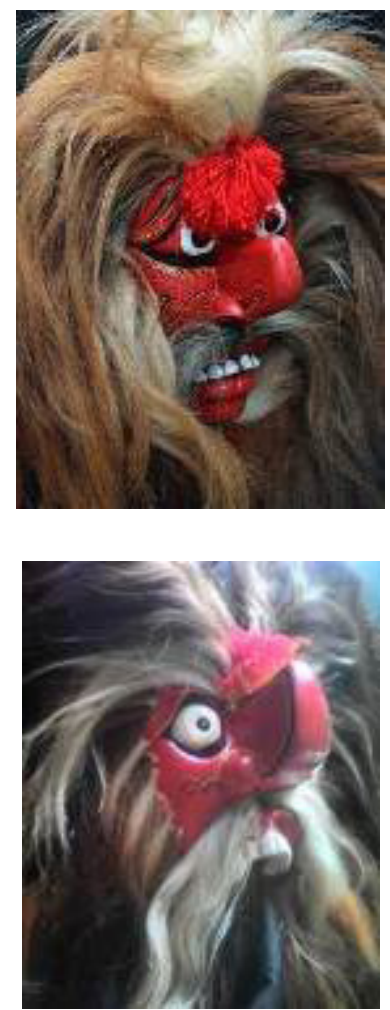

Gambar 5. Refrensi wajah Bujang Ganong dalam https://www.tokopedia.com/kotareyog/topengbujang-ganong-ganongan-reog-2, download oleh Zarkasi 2018

\section{b. Riset Emik}

1) Observasi

Observasi dilakukan untuk mengamati beberapa karya seni rupa yang berbasis seni grafis atau seni cetak yang pernah ada dan melihat potensi-potensi pengembangan yang perlu untuk dilakukan dan dicoba dalam upaya menciptakan karya seni rupa dua dimensi yang inovatif. Beberapa observasi yang dilakukan adalah pada beberapa karya seni rupa yang memanfaatkan teknik benang tarik ini. Hasilnya adalah susunan subyek visual berupa lengkungan, garis abstrak dan goresan efek dari tarikan benang. Jadi belum ada yang memanfaatkan teknik benang tarik ini untuk membentuk satu obyek bentuk manusia atau figur, atau obyek-obyek alam.

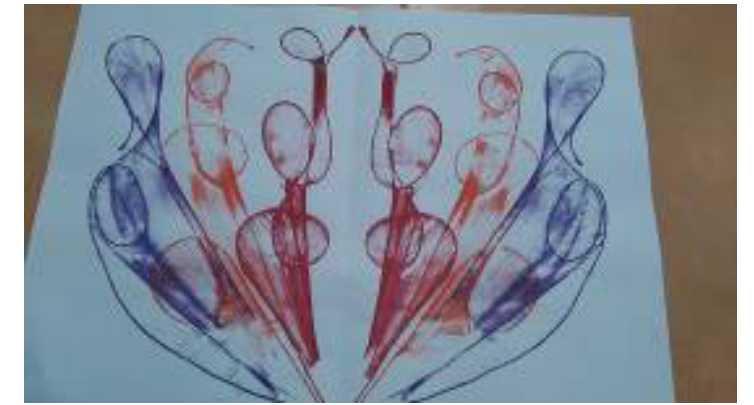

Gambar 6. Refrensi karya benang tarik yang pernah ada dalam http://enisuhartiningsihpsrpgsd. blogspot.com/2015/10/ , download oleh Zarkasi 2018

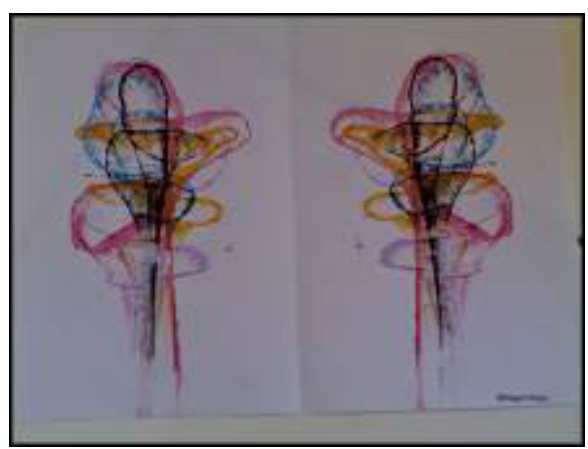

Gambar 7. Refrensi karya benang tarik yang pernah ada dalam http://suchigallery.blogspot. com/2015/09/tata-cara-karya-seni-dwimatra.html , download oleh Zarkasi 2018

Penelitian artistik ini berbeda dengan hasil yang sudah pernah ada terkait benang tarik, yaitu efek dari teknik benang tarik tetap diekspose sebagai kekuatan artistik, namun subjek visual membentuk satu bentuk abstraksi wajah Togog dan topeng Bujang Ganong.

2) Dokumentasi

Teknik ini dilakukan untuk mengumpulkan data yang bersumber dari dokumen (arsip) resmi dan tak resmi di berbagai pustaka, terutama yang terkait dengan penelitian.

\section{Menyempurnakan, Mengembangkan, Memantapkan Gagasan}

Pada usaha menyempurnakan, mengembangkan dan memantapkan gagasan ini, ada beberapa hal yang dilakukan antara lain : 


\section{a. Perenungan}

Pada proses perenungan ini, selain memikirkan tema juga bahasa visual apa yang akan ditampilkan dalam karya. Visualisasinya adalah bentuk wajah Togog dan topeng Bujang Ganong.

\section{b. Kreasi Artistik}

1) Eksperimentasi

Penciptaan karya seni dua dimensi teknik CBT yang hasilnya adalah mono print abstraksi figur tokoh pewayangan ini juga menerapkan prinsip cetak pada proses eksperimentasinya. Benang (yang diberi pewarna) ditata dengan membentuk subjek visual yang diinginkan pada kertas atau kanvas kemudian ditekan dengan bidang datar lain. Setelah itu tali ditarik pelanpelan.

Ada beberapa eksperimentasi dalam proses yang dilakukan terkait pengetahuan alat dan media serta teknik.

a) Alat dan Media Alat yang digunakan terutama adalah benang, yang secara tidak langsung memiliki beberapa jenis dan karakter bila digunakan dalam penciptaan karya CBT ini.

\section{(1) Benang Wol}

Benang Wol memiliki karakter yang lemas tapi tidak halus dan bertekstur ketika diberi warna atau dicetakkan. Benang bahan wol lemas dan menyerap air, sehingga benang yang terkena warna menjadi sangat basah.

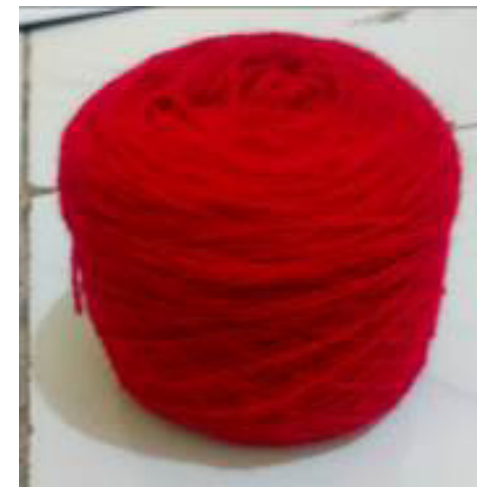

Gambar 8. Refrensi benang Wol, foto oleh Zarkasi 2018

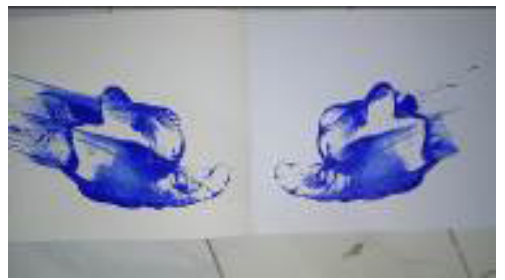

Gambar 9. Hasil eksperimen tarikan dengan benang Wol, foto oleh Zarkasi 2018

Mengantisipasai banyaknya air warna yang terserap benang wol, maka pengeturan keenceran warna menjadi penting.

(2) Benang Jahit

Benang jahit memiliki karakter tipis dan sedikit menyerap air (atau warna akrilik yang berbasis air). Sehingga hasilnya agak tipis. Bila penekanan media datar terlalu kuat, ketika benang ditarik mudah sekali putus. Namun karakter tipis dari benang jahit memiliki bentuk artistik sendiri, yang bisa digunakan dalam memunculkan goresan tarikan yang tipis.

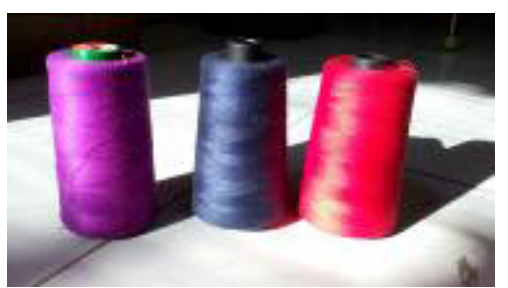

Gambar 10. benang jahit, foto oleh Zarkasi 2018 


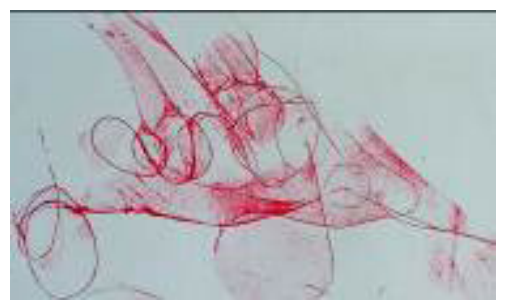

Gambar 11. Hasil eksperimen tarikan dengan benang jahit,

foto oleh Zarkasi 2018

\section{(3) Benang Nilon}

Benang Nilon memiliki karakter yang licin dan tidak menyerap air. Benang nilon ini karakternya keras dan warna yang muncul dari hasil tarikan terkesan tidak merata (sebab warna tidak menempel maksimal pada benang).

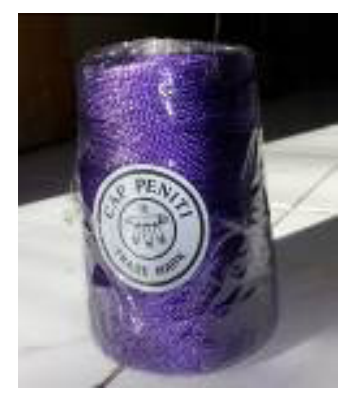

Gambar 12. benang nilon, foto oleh Zarkasi 2018

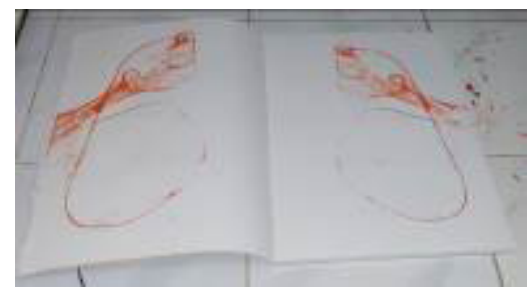

Gambar 13. Hasil eksperimen tarikan dengan benang nilon, foto oleh Zarkasi 2018

(4) Benang Kasur

Benang kasur adalah benang yang sering dipilih dalam pembuatan karya dengan teknik CBT. Benang kasur saat masih baru biasanya mengandung lapisan pati kanji, sehingga agak kaku dan tidak menyerap air. Saat akan digunakan harus dibasahi dulu kemudian diusap dengan kain untuk mendapatkan kelembapan benang, sehingga mudah dalam menyerap cat warna akrilik yang berbasis air.

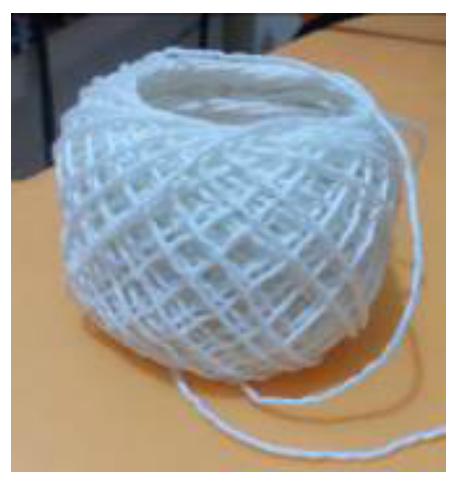

Gambar 14. benang kasur, foto oleh Zarkasi 2018

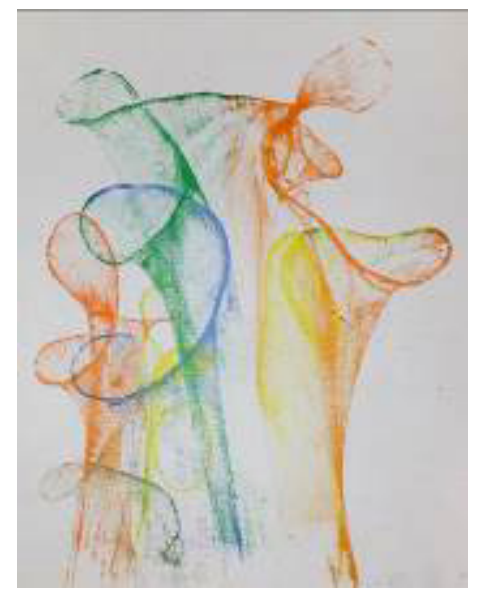

Gambar 15. Hasil eksperimen tarikan dengan benang kasur,

foto oleh Zarkasi 2018

\section{b) Teknik CBT (Cetak Benang Tarik)}

Teknik CBT, ini secara teknis sangat mudah, kita tinggal menyiapkan benang yang kemudian kita beri warna. Benang berwarna tersebut ditempelkan pada kertas atau kanvas (bidang dua dimensi) kemudian ditutup dengan media kertas lain yang datar. Ditekan dengan tangan atau media datar lainnya. Sisa benang yang ada di luar himpitan kertas kemudian ditarik. Ketika dibuka tampak visual hasil benang tariknya. Namun permasalahannya adalah bagaimana mengontrol tarikan benang bisa membentuk subjek visual sesuai dengan keinginan kita membentuk wajah Togog dan topeng Bujang Ganong?

Percobaan atau eksperimentasi yang dilakukan adalah memahami karakter alat 
medianya, yaitu benang dan pembentukan pola visual yang sesuai dengan bentuk yang diharapkan, meminimalisir ketidaksengajaan, menjadi keterencanaan. Guna membentuk subjek visual wajah tokoh pewayangan atau figur tokoh pewayangan tidak bisa satu kali proses tarikan benang, namun beberapa kali sesuai dengan bentukan yang dibuat. Sehingga lebih terkontrol bentuknya. Contohnya membuat kepala tokoh raksasa dalam pewayangan, maka antara lingkar wajah, hidung, mata, gigi dan lainnya dibuat berulang dan dikuatkan dengan membuatnya secara satu persatu dengan cara benang tarik. Lingkar wajah dulu, dibuat dengan benang yang diberi warna dan ditekan dengan kertas serta ditarik, kemudian ditimpa lagi pembuatan hidung, mata, dan seterusnya sampai terbentuk subjek visual yang kita inginkan.

\section{Visualisasi Pada Media}

\section{a. Persiapan}

Adapun alat media yang dipakai dan digunakan adalah :

1) Alat:

a) benang (benang wol, benang jahit, benang kenur, benang bahan nilon)

b) stik kayu

c) Kain lap

2) Media :

a) cat aklilik

b) kertas gambar

c) kanvas

d) media datar untuk menekan

e) air

\section{b. Proses Perwujudan Karya}

Proses ini diawali dengan percobaan menyusun benang pada kertas atau kanvas sesuai susunan bentuk yang diharapkan. Susunan benang ini menjadi acuan susunan cetakan dari benang yang sudah diberi warna, pada proses selanjutnya. Setelah diamati dan yakin bentuk susunan benang membentuk subjek visual yang diinginkan, benang diambil dan diberi warna sesuai rencana awal.
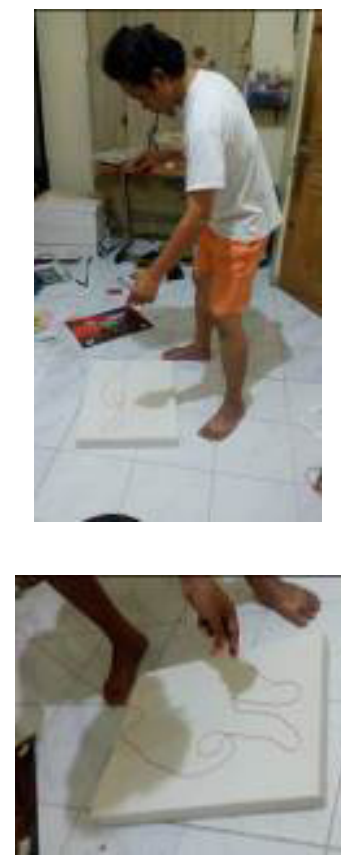

Gambar 16. Penyusunan benang tarikan dengan benang kasur, foto oleh Zarkasi 2018

Setelah diberi warna dan disesuaikan kebasahannya, benang disusun kembali pada kertas atau kanvas sesuai bentukan visual yang diinginkan dan direncanakan.

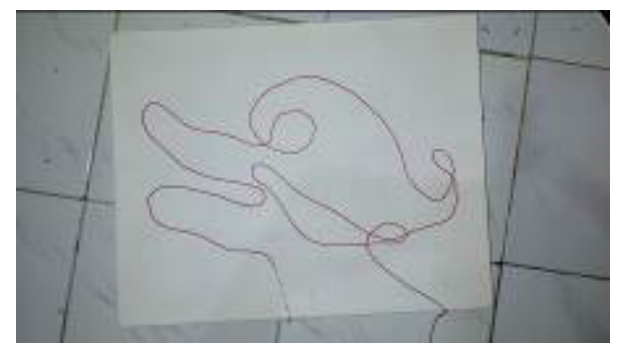

Gambar 17. Penyusunan benang tarikan yang sudah diberi warna pada kanvas, foto oleh Zarkasi 2018

Proses selanjutnya adalah, menutup susunan benang pada kanvas dengan media datar, bisa kertas atau media kanvas lainnya. 


\section{$\tan$}
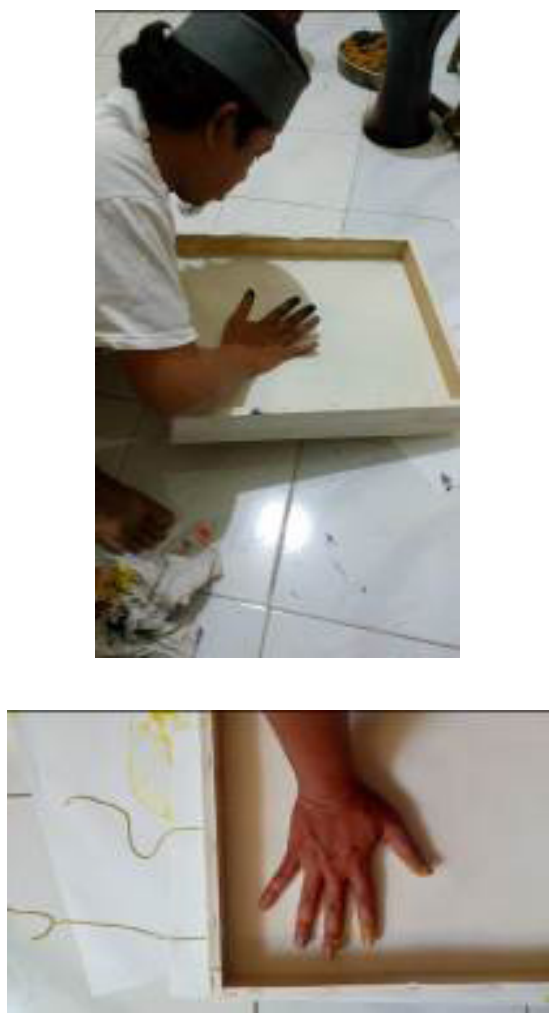

Gambar 18. Penutupan benang tarikan yang sudah diberi warna pada kanvas, dengan kertas atau media datar/kanvas lainnya, foto oleh Zarkasi 2018

Benang yang sudah diberi warna dan tersusun pada kanvas atau kertas ditutup atau ditindih media datar. Proses selanjutnya adalah penarikan benang. Proses penarikan benang ditarik dari sisa benang yang tampak pada bagian bawah kanvas atau kertas sebagai media karyanya. Penarikan bisa diarahkan ke bawah, atau ke samping sesuai dengan rencana bentukan yang ingin dihasilkan.

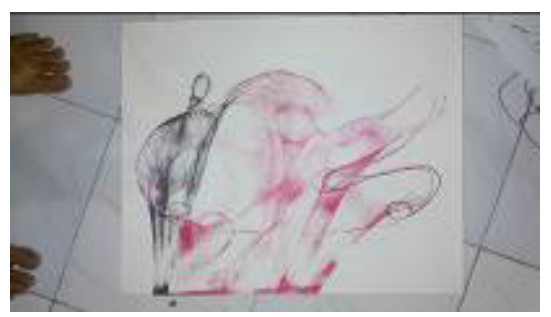

Gambar 19. Hasil penarikan pertama dan kedua dengan warna pertama merah dan kedua hitam, dari proses ekspresi wajah togog, foto oleh Zarkasi 2018
Setelah mengamati hasil tarikan, dilanjutkan penyusunan benang kembali pada media yang sudah ada proses pembentukan gambarnya, sesuai bentukan yang diinginkan, yaitu pembuatan detil mata, atau detil pembentuk subjek visual lainnya. Peoses ini dilakukan berulang-ulang sesuai dengan capaian pembentukan. Proses penarikan dan kebasahan cat pada benang menjadi proses keunikan tersendiri dalam rangka menghasilkan efek yang diharapkan.

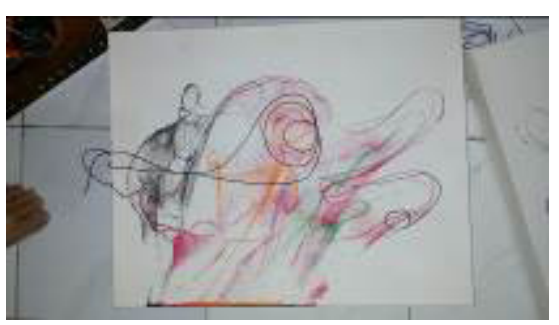

Gambar 20. Hasil penarikan beberapa kali warna lain, untuk menghadirkan kesan artistik dari proses ekspresi wajah togog, foto oleh Zarkasi 2018

\section{c. Evaluasi dan Finishing}

Hasil visual (bentuk dan kesan artistik, estetika karya dengan teknik CBT) diamati dan dilakukan beberapa penembahan detil pada proses finishing.

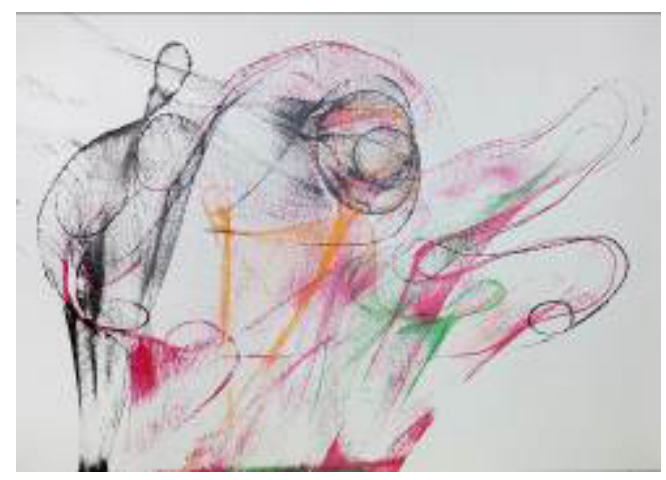

Gambar 21. Hasil finishing untuk menghadirkan kesan artistik dari proses ekspresi wajah togog, foto oleh Zarkasi 2018 


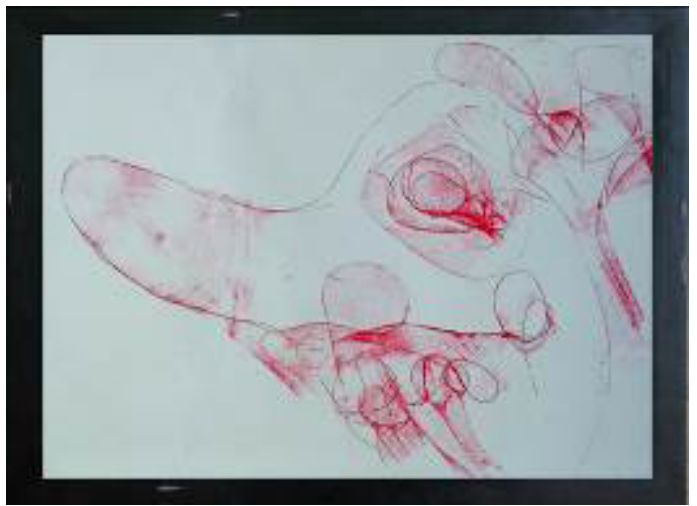

Gambar 22. Bujang ganong \#1 dengan media kertas foto oleh Zarkasi 2018

\section{HASIL DAN PEMBAHASAN}

\section{Karya Berjudul "Togog".}

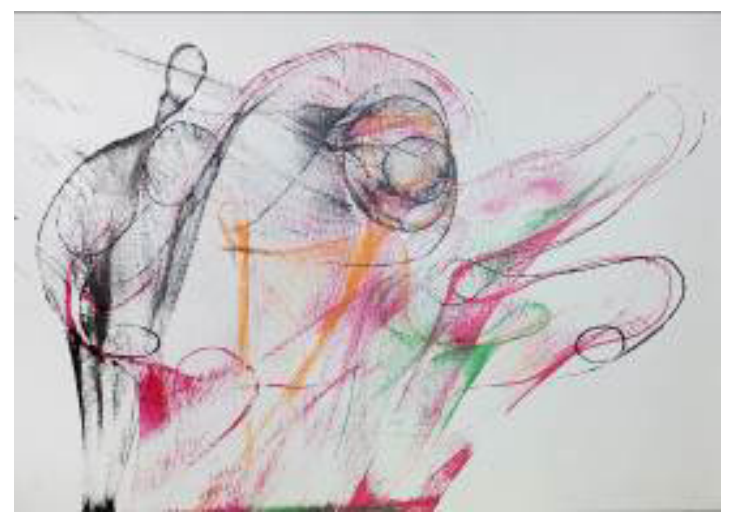

Gambar 23. "TOGOG", 40 x $50 \mathrm{~cm}$, teknik CBT (benang kasur) pada kanvas tahun 2018, foto oleh Zarkasi 2018

Karya ini terinspirasi dari tokoh wayang Togog, yang dikenal pula dengan nama Tejamantri atau Catugora. Ia diyakini sebagai pengejawantahan dari Sanghyang Antaga/Tejamaya, putra sulung dari tiga bersaudara, putra Sanghyang Tunggal dengan Dewi Rekatawati. Dua saudaraya yang lain adalah Sanghyang Ismaya dan Sanghyang Manikmaya.

Togog digambarkan sebagai manusia bermata besar dan bermulut sangat lebar/luas mengkiaskan bahwa ia mempunyai pengetahuan yang sangat luas, karena banyak hal yang diketahuinya. Togog hidup sampai akhir jaman
Purwa. Bahkan pada awal jaman Madya, tokoh Togog masih sering ditampilkan, namun sudah sangat tua.

Karya berjudul "Togog" ini dibentuk dari beberapa kali proses cetakan dengan tarikan benang. Konsentrasi visual dipilih hanya pada wajah dari samping.

\section{Karya Berjudul "Bujang Ganong \#1"}

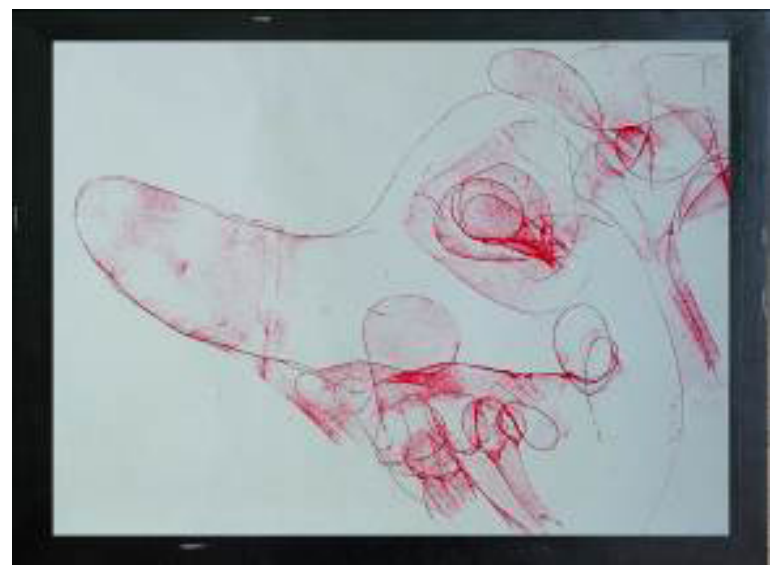

Gambar 24. Bujang ganong \#1, 30 x $40 \mathrm{~cm}$, teknik CBT (benang jahit) pada kertas tahun 2018, foto oleh Zarkasi 2018

Karya berjudul "Bujang Ganong\#1" Terinspirasi dari bentuk artistik topeng Bujang Ganong yang merupakan tokoh dalam cerita pewayangan Panji Asmoro Bangun dan Dewi Sekartaji. Karya ini memvisualkan wajah tokoh Bujang Ganong dari arah samping dan berwarna merah dengan matanya yang melotot.

Visualisasi wajah topeng Bujang Ganong, dibuat menggunakan teknik CBT dengan cat akrilik pada kertas. Benang yang digunakan adalah benang jahit, sehingga karakter efek cetak benang tariknya menghasilkan outline yang lebih tipis. Bentuk wajah Bujang Ganong, dibuat dengan beberapa kali tarikan benang yang dilumuri cat akrilik secara bergantian, mulai dari hidung mulut, gigi, mata dan efek rambut.

Karya ini mengingatkan pada masyarakat untuk lebih mengenal akan budaya sendiri, di antaranya kisah Panji Asmorobangun yang di salah satu ceritanya muncul tokoh Bujang Ganong. 


\section{KESIMPULAN}

Penciptaan Karya Seni Rupa Abstraksi Wajah Togog dan Topeng Bujang Ganong dengan Teknik CBT (Cetak Benang Tarik) ini secara umum sudah terpenuhi secara teknik dan visual, namun demikian perlu dilakukan lagi eksperimentasi yang dalam berkaitan dengan peluang ditemukannya teknik-teknik pembentukan yang bisa memunculkan outline bentuk yang lebih detil, namun tidak mengurangi karakter artistik dari teknik cetak benang tarik.

Pemilihan subjek visual berupa Wajah Togog dan Topeng Bujang Ganong yang dikawinkan dengan teknik eksperimentasi pengembangan teknik teknik CBT diharapkan dapat menambah referensi karya seni rupa yang memiliki karakter keindonesiaan.

\section{DAFTAR PUSTAKA}

Agus Ahmadi, 2014, Kriya Wayang Kulit Purwa Gaya Surakarta, Identifikasi Pola, Aneka Tatahan dan Sunggingannya, cetakan 1, ISI Surakarta Press.

Agus Ahmadi, 1988, "Mengenal Wayang dan Asal-Usulnya (Meyang)", Surakarta:Tiga Serangkai.

Humar, Sahman, 1993,"Mengenali Dunia Seni Rupa", IKIP Semarang Press.

Much. Sofwan Zarkasi, 2007, Figur Wayang Purwa dan Wayang Wong sebagai Sumber Ide Penciptaan Karya Seni Grafis dengan Teknik Komputer, Laporan penelitian DIPA ISI Surakarta 2007.

Much. Sofwan Zarkasi, 2007, Studi Penciptaan Karya Seni Grafis dengan Teknik Hot Print di Aatas Kaca, Laporan penelitian DIPA ISI Surakarta 2008

Rohidi, T. R. (2000), Kesenian dalam Pendekatan Kebudayaan, Bandung, STSI press, 3,1920,

R.M. Sulardi, 1953, Gambar Prinjening Ringgit Purwa, Balai Pustaka, Kementrian P P dan K. Surakarta

Setengah Abad Seni Grafis Indonesia, Jakarta, KPG (kepustakaan Populer Gramedia) dan Bentara Budaya, 2000

Sutopo, HB. (1996), Penelitian Kualitatif ( Sebuah Pendekatan Interpretatif Bagi Pengkajian Proses dan Makna Hubungan antar Subjektif), Surakarta, Universitas Sebelas Maret (UNS) Press.

\section{Sumber Lain}

http://enisuhartiningsihpsrpgsd.blogspot. com/2015/10/

http://suchigallery.blogspot.com/2015/09/tatacara-karya-seni-dwimatra.html

https://www.tokopedia.com/kotareyog/topengbujang-ganong-ganongan-reog-2, 